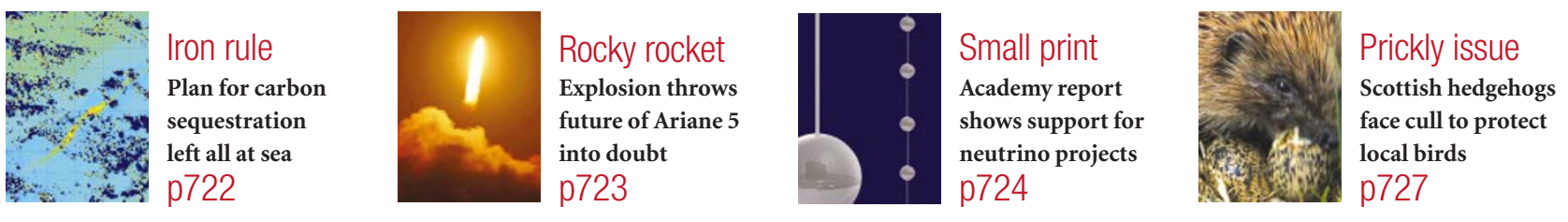

\title{
Stanford announces private plan to get stem-cell research moving
}

\section{Erika Check, Washington}

Stanford University in California is joining a growing list of US universities that are establishing privately funded stem-cell institutes.

In announcing its Institute for Cancer/Stem Cell Biology and Medicine on 10 December, Stanford become the latest institution to attempt to use non-federal money to try to resolve funding and oversight dilemmas in the controversial field of research on human embryonic stem cells. The facility will be headed by Irving Weissman, a prominent stem-cell researchers at Stanford.

The Stanford scientists plan to do basic research on stem cells, and develop new therapies for chronic diseases and cancer. Philip Pizzo, dean of Stanford University's Medical School, said it was "quite feasible" that they would also use a method called therapeutic cloning, or somatic-cell nuclear transfer, to create new embryonic stem-cell lines.

US government regulations expressly prohibit the use of federal money to do this - raising the thorny question of how free universities such as Stanford are to do it, when they depend so heavily on federal government support for other activities.

Two other US universities - the University of California, San Francisco, and Johns Hopkins University in Baltimore, Maryland — opened similar institutes this year.

President George Bush declared in August 2001 that publicly funded researchers would be allowed to work only on stem-cell lines that had already been derived from embryos. And some in the US Congress would like to ban the production of embryonic stem cells altogether, whether researchers are publicly funded or not.

Several states, including California, have passed laws supporting the procedure partly in an attempt to attract biotechnology money. And patient-advocacy groups have convinced some key senators to oppose further restrictions on the research.

Meanwhile, scientists are pushing their universities to find creative ways to fund the work, which could lead to profitable patents and treatments. A handful of institutions have taken the plunge — but others have remained reticent.
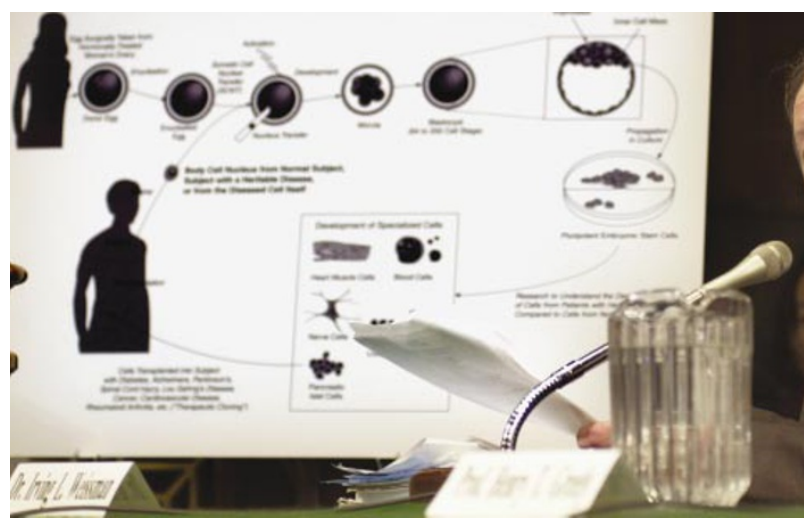

Irving Weissman will head the Stanford institute, which may create new embryonic stem-cell lines.

"Doug Melton [a Harvard University biologist] and I have spent countless hours in the past two years trying to stimulate Harvard and the Boston area into doing a coordinated stemcell programme," says George Daley of the Whitehead Institute for Biomedical Research in Cambridge, Massachusetts. "But I think they're going to be slow to come to the idea."

This is largely because universities are keen to avoid open conflict with the federal government. Thomas Murray, president of the Hastings Center, an independent bioethics institute in Garrison, New York, says that such caution is well founded.

"It would not surprise me if the Bush administration attempted to halt or create as many difficulties as possible for researchers in California or Maryland or any other place supportive of the work," Murray says. "And if you want to make a hard time for somebody and you have the resources of the federal government, you can be creative."

\section{CERN collider project back on track}

\section{Alison Abbott, Munich}

The governing council of CERN, the

European particle-physics laboratory, has approved an eight-year financial plan that will focus tightly on its main project, the Large Hadron Collider (LHC).

The plan's approval should end a period of uncertainty at the lab, after the emergence of hefty cost overruns on the LHC, and problems with the manufacture of its 1,000 or so superconducting magnets (see Nature $413,441 ; 2001)$. The project is now due to be finished in 2007, two years later than planned.

"There have been hiccups and bumps with the LHC, as happens with very big projects," says Luciano Maiani, CERN's director general. "But although resources are tight, we are now on course to make it happen."

The council also elected Robert Aymar, a French plasma physicist, to take over from Maiani in 2004. Aymar is currently director of ITER, an international project to build an experimental fusion reactor. But he is well acquainted with the LHC, having chaired the external review committee established last year to advise the CERN council on how to bring the project back under control.

CERN's previous heads have all been highenergy physicists, but Aymar says he plans to make an asset of his different background. "I will be free of any prejudice," he says, adding that he will appoint a deputy who is more familiar with CERN's scientific work. 